\title{
Academic Mobility and Immigration Trends in South African Higher Education Institutions
}

\author{
Ashika Maharaj \\ University of KwaZulu-Natal, Durban, South Africa \\ maharajash@ukzn.ac.za
}

\begin{abstract}
This paper seeks to offer an insighton the subject of academic mobility into South African Higher Education Institutions (HEI's). This is done by examining the current academic landscape in South Africavia a comparisonbetween the profile of South African (SA) academics andexpatriate academics. Currently, SA is facing major skills and staffing shortages locally in terms of Science, Engineering and Agriculture. The Departmentof Higher Education and Training as well as SA universities have advocated to run programmes in scarce skills disciplines through the recruitment of expatriate academics. The research reported in this paper adopted a non-experimental research design of ex post facto type, using a correlational approach. The data used are the statistical records of all academics in South African higher education for the 2005/2010/2014 academic years as provided by the Higher Education Management Information Systems (HEMIS) of SA. Descriptive statistics as well as inferential statistics were also used to analyze the data. The results revealed that there were no significant differences in age between SA and expatriate academics nationally over the three years. A comparison of the academic qualifications of SA and expatriate academics over the three years indicates that expatriate academics are more highly qualified than their SA colleagues, as the majority of the former hold a doctoral degree. The majority of expatriate academics are recruited from SADC countries as well as other African countries. Interestingly enough, the next most frequent major supply region of expatriate academics to South Africa is Europe. WITS and UCT were consistently ranked first and second in terms of the number of expatriate academics employed over the three years. Both are among the leading five higher education institutions in South Africa in terms of their research outputs as well as the number of PhDs per member of staff.
\end{abstract}

Keywords: Skills Shortages; Academic mobility; Expatriate Academics

\section{Introduction}

This paper seeks to explore the staffing trends in South African higher education, to identify the staff and skills shortages currently experienced. One of the ways to solve the problem in SA is to recruit expatriate academics to staff so-called scarce skills disciplines. This presents a growing opportunity for international mobility of expatriate academics into SA. In fact, recently more people are spending time away from their home countries for work purposes than ever before (Inkson and Myers, 2003; Dickmann and Baruch, 2011). This paper identifies the need for expatriate academics in SA higher education. Secondly, it identifies the disciplines and universities that recruit expatriate academics in SA. Furthermore, it compares the age, gender and qualifications of SA and expatriate academics in SA higher education in order to shed light on the critical need these valuable human resources are filling. Globalisation has seen an increase in the need for organizations to remain competitive, be it through the services and products they provide or the human resources they possess. In a bid to gain competitive advantage over their competitors, organizations are increasing seeking to move their operations internationally to take advantage of cheaper or better quality resources. This has pre-empted the use of expatriates to staff these international operations. A 2011 report by the United Nations Department of Economic and Social Affairs estimated that "there were approximately 214 million people engaged in international mobility; this represented 3.1\% of the total global population" (Dickmann and Baruch, 2011:139) and this number is expected to rise exponentially over the next decade.

Academia is another field of work that uses expatriates to achieve its organizational objectives. Increasingly, universities are seeking to attract highly skilled academics to their institutions to maintain or boost their competitive advantage in the global marketplace. Academics tend to be highly skilled individuals who know the value of their own employability and hence are able to make their own choices when it comes to 
international mobility. Globalisation and, to a lesser degree, regionalization have led to intricate patterns of academic mobility. Within the northern hemisphere, many academics migrate to the United States of America (USA) and Canada from the United Kingdom (UK) due to deteriorating working conditions (Welch, 2003; MORE 2, 2013). Many African countries, like those in the Southern African Development Community (SADC) region, find that they are losing their highly skilled individuals, including academics, to South Africa (brain gain), while South Africa suffers a brain drain to the UK, the USA, Canada, Australia and Dubai (Jansen, 2013). "SA is losing artisans, technicians, doctors, nurses, teachers and accountants in increasing numbers" (Rasool, 2010:34). A recent study has found that $40 \%$ of skilled South Africans across all race groups are considering emigrating (Rasool, 2010). In comparison, in 2000, the number was a mere 18\% (Bissekar and Paton, 2005:20). According to the Centre for Enterprise Development (CDE, 2007a:17), population pyramids reveal that there is large-scale emigration of whites between the ages of 25 and 34 years, the most economically active and skilled group. This is supported by figures from host countries such as the UK and Australia endorsing significant emigration from South Africa for the period 1995-2005 (CDE, 2007a:17). This phenomenon is referred to as 'brain drain' and describes the migration of highly educated, highly skilled workers from their countries of origin to countries that are more attractive in terms of salary, working conditions and living conditions (Nerdrum and Sarpebakken, 2006; Lewis, 2011; Rasool, Botha and Bisschoff, 2012). This phenomenon, together with the prevailing skills shortages and HIV/AIDS, has led to the current crisis in South Africa.

Higher Education South Africa (HESA) has recognized that academia is not "a particularly attractive career option because of relatively low salaries, expanding student numbers and heavy workloads" (Jansen, 2013:1). Sehoole (2012) has argued that the conditions of service at South African universities are unfortunately not uniform across all institutions and in any event, salaries in academia could not compete with those in the private sector. A contributing factor to this dichotomous situation is the deterioration of the academic quality of life due to less than ideal staff to student ratios (Jansen, 2013). These are some of the complexities of the dynamic situation in South African higher education today. Other regions like the Middle East have witnessed an influx of Egyptian, Jordanian and Palestinian academics into Arabian Gulf universities as they are attracted by the superior salaries and more suitable working conditions than those in their home countries (Altbach, 2004: 67). Indian and Pakistani academics are enticed by similar 'pull' factors to countries in the Arabian Gulf, South-East Asia, the USA and Canada. Singapore and Hong Kong have drawn in academics from all parts of the world. Mexico and Brazil entice academics from other South American countries (Altbach and Knight, 2007; Altbach; Reisburg and Pacheo, 2012:7). Academic migration takes place at all levels of the academic system, especially in the sciences, engineering, information technology and some management areas. Such migration may occur more at the top of the systems with some world famous academics being attracted abroad by high salaries at top universities and at the bottom where modest salaries are able to lure foreigners but are unappealing to local applicants (Maharaj, 2011).

To the extent that the overseas sabbatical has been a longstanding feature of many academic careers; Baruch and Hall (2004:254) suggest that faculty have "led the way on the now-popular business trend towards international assignment." However, many academics are now engaging in international mobility beyond an overseas sabbatical. This trend can be related to certain broader social movements. In particular, the rapid expansion of education after the Second World War led to a dramatic increase in the number of universities in many countries (Welch, 2003). Of particular significance was the move from "elite" to "mass" higher education in for example, Canada, UK, USA, and Australia. In addition, the more recent expansion of education throughout Asia, the Middle East and South America, has given rise to an international demand for more faculty to fill the growing number of positions available. In supporting this expansion, successive governments have sought to make tertiary education accessible to an increasing student body. Yet, they have paid less attention to ensuring an appropriately qualified and experienced supply of faculty to fill the newly created positions. Consequently, many institutions are recruiting internationally - a move which is also supported by the putative 'internationalization' of higher education. Indeed, where business education is concerned, institutions are challenged to manage and retain international faculty in order to enhance their status. A study by the Carnegie Foundation for Education of academics in 14 different countries (Altbach et al., 2012) has also linked increasing international mobility with deteriorating working conditions in some countries. This is particularly the case where opportunities for tenure and promotion are concerned. Abolition of tenure in British universities, for example, has brought major changes. Some authors (e.g. 
Trembly, 2004; Altbach et al., 2012) assert that these changes have meant greater flexibility, individual independence and freedom. However, other changes such as the growing number of academics on part-time and/or short term contracts has also meant uncertainty, which some studies suggest has had a detrimental effect on morale (e.g. Kisshun, 2007; Trembly, 2004) and greater willingness to take on overseas positions.

As previously stated, South Africa is facing major skills and staffing shortages in terms of science, engineering and agriculture. The government has created a Scarce Skills List (Kotecha, Lotz-Sisitka and Urquhart, 2014) that identifies key areas in industry that are facing critical staff and skills shortages; this applies to higher education as well. The SA government has put into place policies such as "The Joint Initiative on Priority Skills Acquisition (JIPSA) and the National Development Plan (NDP) 2030" (The Presidency, 2006) to overcome the challenges that together with HIV/AIDS have detracted from South Africa's achieving its postapartheid economic and social goals. The Department of Higher Education and Training (DOHET) has put into place a number of initiatives to help alleviate the problem of staff and skills shortages. In the short term, DOHET has encouraged the recruitment of international talent to allow SA universities to run programmes in scarce skills disciplines to create 'home grown' talent to overcome the staff and skills shortages. SA universities have also sourced international talent to create a 'cosmopolitan feel' to the university in order to become truly international institutions of higher learning (Rasool, Botha and Bisschoff, 2012).

In order to establish the staffing trends in South African Higher Education Institutions over a three year period 2005/2010/2014, the study investigated the profile (qualification/country of origin) of expatriate academics in South African higher education institutions. Furthermore, thestudy establishes the ranking of South African higher education institutions in terms of the number of expatriate academics employed and their countries of origin over the same period.The study also sought to compare and contrast South African academics with expatriate academics in terms of qualifications, age and gender. This was done in order to establish if indeed expatriate academics are coming to South Africa as 'highly skilled talent' in order to fill the current skills gap South Africa faces in terms of its so-called scarce-skills disciplines. This was also done with the intention to identify the top recipient universities of expatriate academics in South Africa to investigate why these institutions were able to attract highly skilled talent over other institutions of higher learning. Finally, the supply regions of expatriate academics to South Africa was investigated in order to determine if the migration of highly skilled labour actually follows the traditional migration trends that is, movement fromSouthern African Development Community (SADC) countries as well as other African countries to South Africa.

\section{Literature Review}

Existing literature on academic mobility in a Higher Education context, provides the background to this study, in terms of global mobility patterns and the challenges facing tertiary learning institutions in the SADC region. By providing a synopsis of the present tertiary education landscape in South Africa, as well as an insight into the skills shortages in South Africa, the discourse shows how this impacts on service delivery in higher education. This study will serve to examine the role played by expatriate academics in servicing the current staff shortages in scarce skills disciplines as well as to provide an accurate reflection of the current higher education landscape by identifying the countries of origin as well as the recipient universities of expatriate academics. Currently, there is a dearth of studies that have examined the academic mobility patterns in South African higher education (Altbach, 2004; Maharaj, 2011; Kotecha, Wilson-Strydom and Fongwas, 2012a). International mobility has long been a feature of academia, with many academics embarking on international mobility in order to develop their careers and to improve their marketability and employability. Often the decision to undertake international mobility rests with the individual. This implies that academics fall into a special category of expatriates called Self-Initiated Expatriates (SIE'S). Traditionally, studies of highly skilled individuals who choose to undertake international mobility have done so based on their perceptions of what is best for themselves and their families in terms of lifestyle and career choices (Bhorat, Meyer and Mlatsheni, 2002; Trembly, 2004; Altbach and Knight, 2007). This study examines the international mobility of the highly 
skilled from a management perspective, focusing on challenges that they face and the benefits they bring to the organization.

Academic mobility has not been limited to any particular academic level or qualification, neither is it limited to migration from south to north, nor to developing countries (Altbach and Knight, 2007). Recent studies have shown that academics will take on various forms of academic mobility, that is, as a visiting academic, spending a sabbatical or even undertaking a permanent relocation, depending on the attractiveness of the opportunities in the host country in terms of salary, lifestyle and working conditions (Nerdrum and Sarpebakken, 2006; Lewis, 2011; Rasool, Botha and Bisschoff, 2012). Traditionally, the view that academic mobility is advantageous to students and staff is commonplace in the higher education literature and has become a universal view adopted by higher education leaders, who see it as an important tool for increasing the capability of higher education systems in developing countries (Altbach, 1996, Altbach and Knight, 2007; Richardson and Zikic, 2007, Kisshun, 2007). More recently, SARUA (2011:11) suggests that: Academic mobility provides faculty and students with personal growth opportunities, improves their prospects of employment, generally improves the quality of teaching and research, and provides access to networks across countries; institutions are able to recruit from elsewhere to strengthen their human resource base and in the case of students, earn valuable income in the contexts of shrinking budgets; and countries are able to strengthen their competiveness and address skills supply constraints. The literature is presented as follows:

- Global academic mobility patterns

- A profile of the Higher Education landscape in South Africa

- Skills shortages in South African Higher Education

Global academic mobility patterns: Globalisation and, to a lesser degree, regionalization have led to intricate patterns of academic mobility. Within the northern hemisphere, many academics migrate to the United States of America (USA) and Canada from the United Kingdom (UK) due to deteriorating working conditions (Welch, 2003; MORE 2, 2013). Many African countries, like those in the SADC region, find that they are losing their highly skilled individuals, including academics, to South Africa (brain gain), while South Africa suffers a brain drain to the UK, the USA, Canada, Australia and Dubai (Jansen, 2013). "SA is losing artisans, technicians, doctors, nurses, teachers and accountants in increasing numbers" (Rasool, 2010:34). A recent study has found that $40 \%$ of skilled South Africans across all race groups are considering emigrating (Rasool, 2010). In comparison, in 2000, the number was a mere 18\% (Bissekar and Paton, 2005:20). According to the Centre for Enterprise Development (CDE, 2007a:17), population pyramids reveal that there is large-scale emigration of whites between the ages of 25 and 34 years, the most economically active and skilled group. This is supported by figures from host countries such as the UK and Australia endorsing significant emigration from South Africa for the period 1995-2005 (CDE, 2007a:17). This phenomenon is referred to as 'brain drain' and describes the migration of highly educated, highly skilled workers from their countries of origin to countries that are more attractive in terms of salary, working conditions and living conditions (Nerdrum and Sarpebakken, 2006; Lewis, 2011; Rasool, Botha and Bisschoff, 2012). This phenomenon, together with the prevailing skills shortages and HIV/AIDS, has led to the current crisis in South Africa.

Higher Education South Africa (HESA) has recognized that academia was still not "a particularly attractive career option because of relatively low salaries, expanding student numbers and heavy workloads" (Jansen, 2013:1). Sehoole (2012) has argued that the conditions of service at South African universities are unfortunately not uniform across all institutions; in any event, salaries in academia could not compete with those in the private sector. A contributing factor to this dichotomous situation is the deterioration of the academic quality of life due to less than ideal staff to student ratios (Jansen, 2013). These are some of the complexities of the dynamic situation in South African higher education today. The most noteworthy challenges academics in African higher education have to contend with are political and legislative challenges, inadequate emphasis on science and technology, admission into and need for higher education, financial constraints, quality control issues, inadequate adoption of ICT's (information communication technology) and poor infrastructure as well as regionalization (Kotecha et al., 2012a:23).

Profiling the higher education landscape in South Africa: There has been a dearth of studies that have sought to profile the higher education landscape in South Africa. The majority of existing studies have 
focused on the demographics of the student population, with very little attention being paid to the demographics of the academic staff population. The section below presents an overview of the South African higher education landscape commissioned by SARUA in 2012, in terms of the number of public tertiary institutions in the country, staff profile in terms of gender, country of origin, major fields of study, highest qualifications and staff shortages. According to the report commissioned by SARUA and completed by Kotecha et al. (2012a:18), there are " 17 publically funded universities and six publically funded technical universities and colleges. The report goes further to indicate that there are 118 privately funded, accredited universities and colleges operating in the higher education sector in South Africa. There are also 50 Further Education and Training (FET) colleges operating in the higher education environment in South Africa". For the purposes of this study, only those institutions that are publically funded, that is, that receive government funding, will be examined; therefore a total of 23 institutions of higher learning will be examined in terms of their staff profile. According to the South African Regional Universities Association (SARUA) report, South African higher education academic staff consists of more male than female staff; this is consistent for both permanent and temporary staff members. This report states that $55.97 \%$ of permanent staff are male, with $44.02 \%$ being female, and $52.17 \%$ of temporary staff are male, with $47.82 \%$ being female. This is consistent with the findings from studies of "other countries in Africa, like Angola, Botswana, Tanzania and Zimbabwe" (Kotecha et al., 2012a:26).

The majority of staff employed by South African higher education institutions are "South African citizens (91.21\%), with $3.06 \%$ of academics from SADC countries (that is, Angola, Botswana, Democratic Republic of Congo, Lesotho, Madagascar, Malawi, Mauritius, Mozambique, Namibia, Seychelles, Swaziland, Tanzania, Zambia and Zimbabwe) and 5.64\% of academics being from other international countries" (Kotecha et al., 2012a:79). Maharaj (2011) undertook a study that specifically examined the profile of expatriate academic staff at South African higher education institutions. The purpose of this study were to identify if there was an increasing number of expatriate academics entering South African higher education institutions for 20002008 , as well as to ascertain the main contributing regions of the expatriate academics. The results indicated that there was an 8\% increase over a 9 year period from 2000-2008 in the number of expatriate academics coming into South African institutions of higher learning (Maharaj, 2011:91). In terms of supply regions African countries contributed almost $50 \%$ of expatriate academics, and Zimbabwe made up the majority of this supply with $20 \%$ of expatriate academics.Europe was the second highest single supplier of expatriate academics to South African Higher Education Institutions (HEI's) with almost 42\%. Asian countries contributed $6 \%$ of the total inflow of expatriate academics, while Australia contributed 2\% in 2008 (Maharaj, 2011:91). Maharaj's (2011) results support the findings of the study commissioned by Carnegie completed by Altbach (1996) as well as of the SARUA study where it was found that South African institutions were recruiting mainly from other African countries.

In the study commissioned by SARUA (Kotecha et al., 2012a: 28), it is demonstrated that the biggest number of academic staff are found in the science, engineering and technology disciplines (27\%), followed by the humanities and social sciences (21\%) and business, management and law (18\%) (Table 2). The study conducted an investigation of staff deficiencies in tertiary education in SA. This revealed that there were staff deficiencies in the science, engineering and technology disciplines, followed by the health sciences, business management and law and agriculture disciplines (Kotecha et al., 2012a:28). This is a manifestation of the situation in South Africa at the moment, with skills shortages in the science, engineering and technology fields. These fields are found on the 2012-2013 Scarce Skills List published by the Department of Labour (DOL) (Kotecha et al., 2014).

The findings of the SARUA study conducted by Kotecha et al. (2012a) show that the number of staff members according to level of qualification has remained consistent when comparing the 2006 and 2010 data. The proportion of academic staff holding a doctoral qualification ranged from 28 to 30\% for 2006 and 2010. Those academics with a Masters qualification ranged from 30 to 31\% when comparing the 2006 and 2010 data. Academics with a post-graduate qualification lower than that of a Masters degree remained the same at $9 \%$, with those academics holding an undergraduate qualification remaining consistent at $18 \%$ for 2006 and 2010 (Kotecha et al., 2012a:30). This is slightly better than the statistics for Africa in general, where only $25 \%$ of all academics hold a doctoral qualification (Cloete, Bailey, Pillay, Bunting and Maassen, 2011:12). This situation would seem to indicate that there is a shortage of highly skilled academics (that is, those with 
doctoral qualifications) in the South African higher education system. The South African government and university management across higher education institutions are cognisant of the issue and have developed innovative policies to improve the problem by 2015 such as increased funding opportunities and the increased availability of post-graduate student support on campuses across South Africa, such as the South African PhD Project (funded by the NRF), and the NDP 2030 (Govender, 2014a:1). Reflecting an annual increase of almost 7\%, the International Education Association of South African (IEASA) reported that there were just under 900000 students registered at higher education institutions in South Africa in 2010 (IEASA, 2011:13). There were 64000 international students at South African higher education institutions in 2010 (IEASA, 2011). This trend means that there will be an increasing demand for appropriately qualified and experienced staff. According to the chairperson of the Education, Training and Development (ETDP) SETA, there is shortage of suitably qualified staff in higher education institutions" (IEASA, 2011:13). In South Africa, academics with doctoral qualifications constitute only $40 \%$ of the staff in public higher education facilities. Even in the most popular research institutions in the country, University of Cape Town and WITS, just under two thirds of the staff have PhDs (IEASA, 2011).

Thus, the implication is that South African higher education institutions are suffering from a skills shortage, as only $40 \%$ of the total number of academics has a doctoral qualification; this seriously impacts on the institutions ability to design, implement and deliver high quality academic programmes (Kotecha et al, 2012a; Govender, 2014a). The profile of the higher education landscape of South Africa provided in this section has served to illustrate the staffing situation at publically-funded universities, universities of technology and technical colleges. This was done with the aim of highlighting the disciplines where staff shortages exist in order to assess whether these disciplines can be categorized on the South African Scarce Skills List 20132014 (Kotecha et al., 2014). In addition, the identification of the proportion of academic staff holding different levels of qualifications illustrated the need to recruit highly skilled academics (those holding a doctoral qualification) in order to fill high level academic posts such as professors and senior lecturers. Furthermore, the aim was to examine the number of expatriate academics at South African higher education institutions in comparison to their South African colleagues and to identify their countries of origin. This served as the foundation upon which to build this study in order to identify where South Africa is currently recruiting its academic human capital from. The next section focuses on the current skills shortages faced by South Africa at large and in particular the higher education context.

Skills shortages in South African higher education: With global higher education facing ever increasingly complex challenges, higher education in South Africa has tried to keep up, while also attempting to improve both its size and quality. Since 2012, there have been many changes to South Africa's higher education landscape. Including the announcement of the construction of two new universities in Mpumalanga and Limpopo provinces and also the introduction of an additional R850 million to develop university infrastructure (Govender, 2014a:1). Moreover, benefactor funding of almost R60 million was made available for the 2012/2013 and 2013/2014 academic year through general budget support (Govender, 2014a:1). A key issue in the South African higher education debate has been producing sufficient skills that are relevant to an economy trying to change itself into a knowledge-based economy. The Minister of Higher Education and Training stated on the 24 May 2012 in The Sowetan newspaper (2012:1) that "we are engaging with higher education South Africa, and deans of relevant faculties to accelerate especially black and women graduate output in these areas to provide the relevant and needed skills for a knowledge economy". Plans included the introduction of a six year scholarship programme to increase the number of black potential academics and provide support for postgraduate qualifications (Govender, 2014a:1). In a survey reportedly done by the Sunday Times newspaper (2014:1) on the 14 September 2014, the pace of transformation at 13 higher education institutions was found to be slow, especially in terms of equity for those holding professor and associate professor posts. The results also indicated that some universities employed large numbers of expatriate academics. This recruitment drive was a consequence of 4000 academics whom were eligible to retire over the next six years thus creating a substantial brain drain on the higher education sector (Govender, 2014a). According to an article by Govender (2014b:1) in the Sunday Timesnewspaper on the 5 October 2014, huge amounts of money was being spent on recruitment of foreign academics countrywide as these institutions try to deal with the growing deficit of suitably qualified academics. 
Govender $(2014 \mathrm{~b} ; 1)$ states that almost $29 \%$ of the teaching staff at WITS and one out of every four academics at UCT are foreign academics. In the article, WITS vice chancellor, Adam Habib argues that the skills shortages are not only in terms of equity but also due to the rapidly aging professoriate. He further argues that even if did not have a shortage of academics, it was important to have an international professoriate as it lends a global vibe to the institution (Govender, 2014b:1). Due to ongoing skills shortages in South Africa, the government had realized that there would be a need to bring in foreign workers to help overcome the shortage and to assist in assimilating South Africa into the global marketplace as well as to make changes to the South African higher education landscape. This need was to be addressed by the South African's government's economic policy known as JIPSA (The Presidency, 2006). The role of the skilled immigrant was seen as having a dual purpose (Rasool et al., 2012:404):

- "firstly, to enhance the economy

- Secondly, to transfer the skills and experience to the local workforce".

This is true in the higher education environment, as experts are needed to train students in scarce skills disciplines to take up positions in areas directly affected by the skills shortages in the country (Govender, 2014a:1). Thus many higher education institutions are now recruiting expatriate academics in an attempt to staff their scarce skills disciplines and to ensure in this way that teaching and learning continues uninterrupted.

\section{Methodology}

This study followed a secondary data review and analysis process that involved collecting information, and statistics at various levels of accumulation in order to allow the researcher to create a situational analysis of the current trends in SA higher education. Secondary data regarding SA academics and expatriate academics was collected from the HEMIS system run by the Department of Higher Education and Training for the three year period, 2005/2010/2014. These statistics were independently verified as reliable and accurate by auditors of HEMIS.

\section{Results}

Country of origin: The countries of origin for expatriate academics in South African (SA) higher education institutions were categorized into the following countries and regions: ZIM (Zimbabwe), ZAM (Zambia), TAN (Tanzania), SWA (Swaziland), SOU (South America), OTH (other African countries), NOR (North America), NAM (Namibia), MOZ (Mozambique), MAU (Mauritius), MAL (Malawi), MAD (Madagascar), LES (Lesotho), EUR (Europe), DEM (Democratic Republic of Congo), BOT (Botswana), AUS (Australia), ANG (Angola) and AIS (Asian countries). In 2005, the highest number of expatriate academics in SA higher education institutions came from Europe (34.1\%). These were then followed by those from other African countries (24.1\%) and then those from Zimbabwe (16.4\%). In terms of SADC countries, the majority of expatriate academics came from Zimbabwe (16.4\%), followed by those from Zambia (4.6\%) and then Malawi (2.3\%). Asian countries contributed $4.4 \%$ of the total number of expatriate academics for 2005 . Australia contributed $1.7 \%$ of academics for 2005, while North and South America together made up 7.6\% of the total number of academics coming into SA higher education institutions.

In 2010, the highest number of expatriate academics in SA higher education institutions came from Europe (27.1\%). The next highest group was from other African countries (23.4\%) followed by those from Zimbabwe (23.3\%). In terms of SADC countries, once again Zimbabwean academics make up the majority (23.3\%), followed by those from Zambia (2.4\%) and then those from Botswana, Lesotho and Malawi each with $2.1 \%$. Asian countries made up $6.4 \%$ of the total number of expatriate academics coming into SA higher education institutions. Australia contributed $1.4 \%$ of the total number of academics coming in for 2010, while North and South America together made up 6.3\% of the total number of expatriate academics for 2010. A change in this trend can be seen in 2014 when highest number of expatriate academics came from Zimbabwe (26.6\%). They were followed by academics from Europe $(23.5 \%)$ and then by those from other African countries $(22.7 \%)$. In terms of SADC countries, Zambia once again was the second largest supplier of academics to South Africa (3.2\%), with the Democratic Republic of Congo (2.2\%) next. Australian academics made up $1 \%$ of the total number of academics coming into South Africa, while Asian countries make up 4.6\%, 
with North and South America together making up 6.9\% of the total number of expatriate academics entering SA higher education institutions.

Over the period 2005/2010/2014, European academics made up (84.7\%) (2005-23.5\%+2010-27.1+2014$34.1 \%)$, other African academics made up (69.5\%) $(2005-22.7 \%+2010-22.7 \%+2014-24.1 \%)$ and Zimbabwean academics (66.3\%) (2005-16.4\%+2010-23.3\% +2014-26.6\%). Findings indicate that South African higher education institutions are mainly recruiting from African countries, especially from SADC countries (Tanzania, Angola, Botswana, Democratic Republic of Congo, Lesotho, Madagascar, Malawi, Mauritius, Mozambique, Namibia, Swaziland, Zambia and Zimbabwe), while European academics make up the second largest recruitment pool after African academics. The statistical analysis (Chi-square test of independence) shows that there is a significant relationship between the year (2005/2010/2014) and country of origin of the foreign academics $\left(\chi^{2}(36, n=3632)=109.69, p<.0005\right)$. Specifically, in 2005 , more than expected came from Europe, Mozambique and Zambia; in 2010, more than expected came from Asia and Botswana; and in 2014 more than expected came from the Democratic Republic of Congo, Lesotho and Zimbabwe. This indicates that more expatriate academics coming to SA are from the SADC region than in previous years. In the next section, the higher education institutions in SA have been ranked in terms of the number of expatriate academics employed for 2005/2010/2014.

Ranking of higher education institutions in terms of the number of expatriate academics employed: Results indicate that the University of the Witwatersrand (WITS) was ranked first across all three years, with 192 expatriate academics in 2005, with 235 expatriate academics in 2010 and 296 expatriate academics in 2014. Second, again for all three years, was the University of Cape Town (UCT) with 80 expatriate academics for 2005, 234 for 2010 and 262 for 2014. Rhodes University (RU) was ranked third in 2005 with 74 expatriate academics, but then slipped to twenty-first out of 23 institutions in 2010 with 8 expatriate academics. Then in 2014, RU was ranked ninth with 48 expatriate academics. The University of Limpopo (UL) was ranked fourth in 2005 with 45 expatriate academics; they then slipped to twelfth place in 2010 with 34 expatriate academics and in 2014 they were ranked eleventh with 44 expatriate academics. In 2005, the University of Pretoria (UP) was ranked fifth with 44 expatriate academics; they remained in fifth position in 2010 with 106 expatriate academics and in 2014 with 90 expatriate academics. University of KwaZulu-Natal (UKZN) was ranked sixth in 2005 with 40 expatriate academics; they then increased the number of expatriate academics in 2010 to 191 and were ranked third, a position they maintained in 2014 with 194 expatriate academics. The University of South Africa (UNISA) was ranked seventh in 2005 with 37 expatriate academics; they then recruited more expatriate academics in 2010 with a total of 111 and moved to fourth position, where they remained in 2014 with 102 expatriate academics. These results illustrate that the two universities that recruited the most expatriate academics over the eight year period remained unchanged, namely, WITS and UCT. The majority of institutions of higher learning in SA show an increase in the number of expatriate academics employed over the eight year cycle, with the exception of RU (Rhodes University), University of Johannesburg (UJ), University of the Western Cape (UWC), University of Fort Hare (UFH), Nelson Mandela Metropolitan University (NMMU) and Walter Sisulu University (WSU). In the next section, a comparison of the number of $S A$ academics versus the number of expatriate academics is made.

Table 1: Proportion of South African versus expatriate academics across 2005/2010/2014

\begin{tabular}{|c|c|c|c|c|c|c|}
\hline \multicolumn{7}{|c|}{ year } \\
\hline & & & 2005 & 2010 & 2012 & Total \\
\hline \multirow[t]{6}{*}{ SA or other } & Other & Count & 701 & 1362 & 1569 & 3632 \\
\hline & & Expected Count & 1118.5 & 1244.4 & 1269.0 & 3632.0 \\
\hline & & Std. Residual & -12.5 & 3.3 & 8.4 & \\
\hline & SA & Count & 14180 & 15194 & 15314 & 44688 \\
\hline & & Expected Count & 13762.5 & 15311.6 & 15614.0 & 44688.0 \\
\hline & & Std. Residual & 3.6 & -1.0 & -2.4 & \\
\hline \multirow[t]{2}{*}{ Total } & & Count & 14881 & 16556 & 16883 & 48320 \\
\hline & & Expected Count & 14881.0 & 16556.0 & 16883.0 & 48320.0 \\
\hline
\end{tabular}


Comparison of SA academics to expatriate academics for 2005/2010/2014: Firstly, a description of the proportion of SA versus expatriate academics across 2005/2010/2014 is presented. Secondly, a comparison of qualifications between SA and expatriate academics has been done. Thirdly, a comparison of the age and gender between SA and expatriate academics has been done.

Proportion of SA versus expatriate academics: Table 1 compares the number of SA academics to expatriate academics across the three years 2005/2010/2014. Over the period represented, the number of expatriate academics has steadily increased from 4.6\% in 2005, to $8.2 \%$ in 2010 and finally to $9 \%$ in 2014 . However, when compared to the number of SA nationals in higher education institutions across the three years, it can be seen that the latter make up the majority of academic staff. However, the number of South African academics has dropped from $92.6 \%$ in 2005 to $87.8 \%$ in 2014, indicating a staff turnover of more than 1134 over an eight-year period.

Table 2: Pearson Chi-Square

\begin{tabular}{llll}
\hline & Value & df & Asymp. Sig (2-sided) \\
\hline $\begin{array}{l}\text { Pearson Chi- } \\
\text { Square }\end{array}$ & $257.213^{\mathrm{a}}$ & 2 & .000 \\
& & & \\
Likelihood Ratio & 275.886 & 2 & .000 \\
$\begin{array}{l}\text { Linear-by-Linear } \\
\text { Association }\end{array}$ & 256.327 & 1 & .000 \\
N of Valid Cases & 48320 & & \\
\hline
\end{tabular}

a. 0 cells $(.0 \%)$ have expected count less than 5 . The minimum expected count is 1118.54 .

Chi-square analysis on records of staff of known nationality shows that significantly more than expected are expatriate academics in 2010 and 2014, while more than expected were SA in $2005\left(\chi^{2}(2, n=48328)=257.21\right.$, $\mathrm{p}<.0005)$. This trend would signify that more expatriate academics are coming into South Africa than in previous years. In the next section, the qualifications held by SA and expatriate academics is compared.

Comparison of qualifications: SA vs expatriate academics: In order to simplify the analysis, qualifications have been grouped as follows:

- Undergraduate (Undergraduate diploma/certificate; General academic Bachelor's degree; Professional First bachelor's Degree)

- Postgraduate (Postgraduate Diploma/Certificate; Postgraduate Bachelor's degree)

- Honours

- Masters

- Doctorate

- National Diploma/Certificate (Undergraduate Diploma/certificate; National Certificate; National Higher Certificate; National Diploma; Post-diploma Diploma; National Higher Diploma)

- Academic Technical (Baccalaureus Technologiae (B.Tech); Masters Diploma in Technology; Magister Technologiae (M.Tech); Doctor Technologaie (DTech).

- Other qualifications.

Results indicate that in 2005, expatriate academics held more doctoral degrees $(54.5 \%)$ than their SA counterparts (28.4\%), although SA academics held more Honours (9.2\%) and Masters degrees (30.5\%) than their expatriate academic counterparts. A similar situation to the previous one exists for technical qualifications such as B.Tech, M.Tech and D.Tech qualifications (5.1\%) where SA academics hold more of these qualifications than their expatriate colleagues. In 2010, more expatriate academics held doctoral degrees (57.1\%) than their SA counterparts (32.9\%). SA academics held more Masters (32.7\%) and Honours degrees $(8.3 \%)$ than their expatriate counterparts. In terms of technical qualifications, SA academics held more qualifications (6.7\%) than their expatriate counterparts (2.2\%). In 2014 once again expatriate academics held the most doctoral degrees $(60.3 \%)$ in comparison to their SA counterparts $(35.2 \%)$, while SA 
academics still held more Masters (32.3\%) and Honours qualifications (9.8\%). With regard to technical qualifications, SA academics accounted for $6.7 \%$ and expatriate academics only $2.9 \%$. These results establish that expatriate academics in SA higher education institutions are highly qualified, mostly with doctoral degrees, and that they have steadily increased in proportion from 2005 (54.5\%) to 2014(60.3\%). Chi-square test of independence (or Fisher's exact, where conditions are not met) was applied to see if there is a significant relationship between SA/expatriate academics and qualifications for each of the three years. The results show that in 2005 significantly more than expected expatriate academics had a doctoral degree $\left(\chi^{2}\right.$ $(19, \mathrm{n}=14679)=290.00, \mathrm{p}<.0005)$. In 2010, significantly more expatriate academics had a doctoral degree or another qualification, while more than expected of the SA academics had a national higher diploma, a B.Tech., Honours, Masters or Professional first bachelor's degree $\left(\chi^{2}(22, n=16556)=417.27, p<.0005\right.$. In 2014, significantly more expatriate academics had doctoral degrees, undergraduate diplomas or certificates or Bachelor's degrees (3 years), while local academics were qualified with more national higher diplomas or B.Tech., Honours, postgraduate Bachelor's or Bachelor's degrees $\left(\chi^{2}(27, n=16883)=491.21, p<.0005\right)$. This trend would serve as evidence that expatriate academics are better qualified in terms of skills and qualifications than their South African counterparts. In the next section a comparison of the age and gender of SA versus expatriate academics over the three years 2005/2010/2014 is presented.

Comparison of age and gender: SA vs non-SA: In Table 3 below a comparison of the age of SA versus expatriate academics for $2005 / 2010 / 2014$ is made. Firstly, for 2005, the average age of SA academics was 43.44, while the average age of expatriate academics was 44.03. This shows that South African academics were slightly younger than expatriate academics on average for 2005. Secondly, in 2010, the average age for expatriate academics was 42.90 while the average age for SA academics was 44.56 . Finally, for 2014, the average age for expatriate academics was once again 42.9 while the average age for SA academics was 44.74 .

\begin{tabular}{|c|c|c|c|c|c|}
\hline Yea & & SA or other & $\mathbf{n}$ & Mean & Std. deviation \\
\hline 20 & Age & Other & 701 & 44.03 & 9.26 \\
\hline 05 & & SA & 14180 & 43.44 & 9.90 \\
\hline 20 & Age & Other & 1362 & 42.90 & 9.43 \\
\hline 10 & & SA & 15194 & 44.56 & 10.36 \\
\hline 20 & Age & Other & 1569 & 42.90 & 9.19 \\
\hline 14 & & SA & 15314 & 44.74 & 10.43 \\
\hline
\end{tabular}

Chi-square tests illustrate that while the average age is not significantly different in 2005 for the two groups, that is SA and expatriate academics, there is a significant difference in $2010(\mathrm{Z}(\mathrm{n}=16556)=-6.13, \mathrm{p}<.0005)$ and $2014(\mathrm{Z}(\mathrm{n}=16883)=-7.25, \mathrm{p}<.0005)$. Over the three years, results indicate that the average age for SA academics is higher than for non-SA academics. Also, expatriate academics are coming into SA at a younger age than in previous years. A comparison of the distribution of gender for SA academics versus expatriate academics for the three years 2005/2010/2014. The analysis also shows that for 2005 there are significantly more males than females amongst SA academics (58\% male) and more males than females amongst expatriate academics, $2005-\left(\chi^{2}(1, \mathrm{n}=14881)=92.21, \mathrm{p}<.0005\right)$. In 2010 , there are significantly more males that females among SA academics (54\%) and more males than females amongst expatriate academics $\left(\chi^{2}(1\right.$, $\mathrm{n}=16556)=248.93, \mathrm{p}<.0005)$. In 2014, there are significantly more males $(53 \%)$ than females amongst SA academics and more males than females amongst expatriate academics too $\left(\chi^{2}(1, n=16883)=306.35\right.$, $\mathrm{p}<.0005)$. The gender patterns over the three years amongst expatriate academics and SA academics points towards more male academics than female academics for both groups. The context in which this study takes place is UKZN therefore in the next section, the staff profile of the university was investigated to compare SA to expatriate academic staff in terms of age, gender, qualifications, field of study and level of academic post for $2005 / 2010 / 2014$. This was done in order to establish how the profile of academic staff at UKZN compares to that of that of the SA higher education landscape.

Discussion of Results: A comparison of the ages of SA and expatriate academics in 2005 there were no significant age differences between these two groups. However, for 2010 and 2014 there were significant age differences, where the average age of SA academics was higher than that of expatriate academics. Expatriate academics' average age over the three years ranges from 44.03 to 42.90 . The youngest expatriate academics 
over the three years were 24 years old and the oldest range from 65 to 70 years old. This finding corresponds to the characteristics of highly skilled talent identified by Suutari and Brewster (2000) where highly skilled talent were generally slightly younger than their local colleagues. When comparing the gender of SA academics versus expatriate academics, results showed that there have been significantly more males than females among SA and expatriate academics for 2005/2010/2014 across all SA higher education institutions. In the SA context, amongst SA academics these findings bear testimony to the fact that, twenty years into democracy, SA was still struggling to address the gender imbalances of its past, where women were not part of the traditional economically active population and where their social roles as wives and mothers defined their social identities and they did not have access to education. The trend amongst expatriates was indicative of the gender bias pointed out in migrant and expatriate management literature (Selmer and Lauring, 2013; Altman and Baruch, 2012; Aycan and Eskin, 2005) where it was shown that individuals who move to another country are traditionally male due to pre-existing social differences between genders. These findings were in contrast to the findings of Suutari and Brewster (2000) who found that highly skilled talent are mainly females. It is important to note the context of Suutari and Brewster's (2000) study as their sample was from European countries, unlike the current study.

A comparison of the academic qualifications of SA academics and expatriate academics in SA higher education institutions revealed that the majority of expatriate academics held doctoral degrees: $54.5 \%$ in $2005,57.1 \%$ in 2010 and $60.3 \%$ in 2014.The results of the study show that the expatriate academics at SA higher education institutions were highly qualified, highly skilled and were experts in their fields. When compared to the qualifications of SA academics over the same period, with only $28.4 \%$ in 2005 holding doctoral degrees, only $32.9 \%$ in 2010 and only $35.2 \%$ in 2014 . A chi-square test of independence was applied to the findings to see if there was a significant relationship between SA and expatriate academics and their qualifications over the three years. The results indicate that in 2005, significantly more expatriate academics held doctoral degrees $\left(x^{2}(19, \mathrm{n}=14679)=290.00, \mathrm{p}<0.05\right)$. In 2010, more expatriate academics held doctoral degrees and/or other qualification, while SA academics held more Masters, Honours, Professional first degrees and/or B.Techs $\left(x^{2}(22, n=16556)=417.27, \mathrm{p}<0.05\right)$. In 2014 , significantly more expatriate academics held more doctoral degrees, undergraduate diplomas or certificates or Bachelors' degrees (3 years) than SA academics $\left(x^{2}(\mathrm{n}=16883)=491.21, \mathrm{p}<0.05\right)$. This situation supports the premise that there was a shortage of highly qualified and highly skilled local academics in SA higher education. This finding provides empirical evidence of the ongoing plans by the Department of Education to spend more than R30 million a year to hire academics from developing countries on fixed term contracts to solve the current skills and staff shortages in higher education in SA (Govender, 2014a). It also supported the findings of previous studies commissioned by SARUA (Kotecha et al., 2012a).

However, the SA situation remained better than that in most African countries, where only $25 \%$ of all academics held a doctoral degree (Cloete et al., 2011). Due to the skills shortage in SA higher education, there has been a need to bring in the necessary skills and expertise in order to deliver the appropriate teaching and learning programmes at higher education institutions in order to grow and develop the new generation of SA workers. This priority was part of JIPSA (The Presidency, 2006), where the highly skilled expatriate serves two purposes. According to Rasool et al. (2012:404), they firstly enhanced the economy by bringing in much needed skills and expertise and, secondly, they were able to transfer their skills and knowledge to the local workforce, which in this context are the students and staff at institutions of higher education. Results also indicate the number of SA citizens in higher education had dropped significantly from 2005 to 2014, provided empirical evidence to support the views of the ETDP and Cloete et al. (2011). The figures have dropped from $92.6 \%$ in 2005 to $87.8 \%$ in 2014 . This trend indicated a staff turnover of SA academics of more than 1134 over the eight year period. This finding was supported by Kotecha et al. (2012a) whose survey found that SA higher education is currently facing staff shortages in the science, engineering and technology fields, followed by the health sciences, business management and law and agriculture fields. During the same period, there was a steady increase in the numbers of expatriate academics being recruited in SA higher education. Thus, it becomes evident that expatriate academics were being recruited to solve the current staff shortages in SA higher education, especially in the scarce skills disciplines.

The countries/regions of origin of the expatriate academics in SA higher education for 2005/2010/2014 were examined in order to determine the source of SA's highly skilled foreign talent. Zimbabwe has been the 
largest single country to contribute to academics to South Africa over the three years. SADC countries, including Zimbabwe, contributed 34\% of the total number of expatriate academics in South Africa in 2005, $35.5 \%$ in 2010 and $41.4 \%$ in 2014 . A chi-square test showed that there was a significant relationship between the year $(2005 / 2010 / 2014)$ and the country of origin $\left(x^{2}(36, \mathrm{n}=3632)=109.69, \mathrm{p}<0.0005\right)$. Specifically in 2005, more than expected academics came from Europe, Mozambique and Zambia. In 2010, more than expected came from Asia and in 2014, more than expected came from the Democratic Republic of Congo, Lesotho and Zimbabwe. The other major suppliers of expatriate academics to SA from SADC countries are Zambia and Malawi. This was consistent with the findings of Altbach (1996), Maharaj (2011) and Kotecha et al. (2012a), who also found that SA universities were primarily recruiting from African, especially SADC, countries. The results of the study also showed that Europe was a major contributor of academics to SA higher education over the three years, with $23.5 \%$ of the total number of expatriate academics in SA for 2005, $27.1 \%$ in 2010 and $34.1 \%$ in 2014. These findings support previous studies by Maharaj (2011). These findings contrast with traditional migration patterns of European academics, who normally travel either to the United Kingdom or the Americas. This could be the result of them seeking a relatively untapped research context, in South Africa.

The results show that Asian countries have contributed between $4-6 \%$ of the total number of expatriate academics over the period under investigation. The results were consistent with the literature that showed that individuals relocate to destinations where there is less cultural distance between the home country and the host country so that there is minimal "culture shock" (Hofstede and Hofstede, 2005). Relocating to SA that has been called the 'rainbow nation' implies that there is a melting pot of diversity and culture present in SA society. African, European and Asian cultures are present in SA society today as these groups make up the diversity that makes up SA today. Unfortunately, in as much this could be why many expatriate academics come to SA, current feelings of xenophobia taint this perception. This is because of the high employment rates amongst local citizens who feel that foreigners are here to take their jobs (MacFarlane, 2012; Ngcobo, 2013). These findings were consistent with the findings by Jansen, (2013), who found that many African countries, like those in the SADC region are losing their highly skilled academics to South Africa because of the deterioration of working conditions and political and socio-economic instability. MORE 2 (2013) also found that many European academics were choosing to relocate to other regions around the world for the same reasons. Altbach and Knight (2007) and Altbach et al. (2012:12) found that "Indian and Pakistani academics also were motivated by similar reasons and were attracted by the better working conditions and higher salaries in regions such as the Arabian Gulf, South-East Asia, the Americas and South Africa". These types of reasons are called 'push and pull factors'. Above, the possible 'push factors' that attracted expatriate academics to SA have been probed. In the next section, the possible 'pull factors' that attracted academics to SA are discussed.

The recipient universities of expatriate academics in SA were ranked according to the number of expatriate academics employed over the three years and indicated that WITS was the number one ranked institution in SA in terms of the number of expatriate academics employed over the three years. UCT was ranked second over the three years. Previous studies have indicated that international academic migration is focused on 'magnet' institutions (Knight, 2006; Regenesys Business School, 2013). These two institutions have been recognized as the most popular research institutions in the country, where just under two thirds of the staff have PhDs (IEASA, 2011). In fact Govender (2014b) claims that at least 29\% of teaching staff (academics) at WITS and one out of every four academics at UCT are expatriates. WITS based in Johannesburg was the country's second highest ranked institution and improved by a huge 50 positions to 313 on the Quacquarelli Symonds (QS) World University rankings for 2013. The world-wide ranking scale known as the Quacquarelli Symonds(QS) ranking for 2013/2014 ranked UCT at 145, making it the highest ranked African and SA university on the world rankings (MacFarlane, 2013; Quacquarelli Symonds Limited, 2014). In the three years examined, UP, UKZN and UNISA remained in the top ten ranked higher education institutions employing expatriate academics. Of these universities, UZKN and UP together with Stellenbosch University also appear in this list. They also appear on the Top 100 Emerging Economies university rankings list developed by the Times Higher Education group in an effort to rank the universities in Brazil, Russia, India, China and South Africa (BRICS). Best Global Universities (2014) ranked UCT at 151 for 2014, once again making it the highest ranked SA university, followed by WITS at 270, Stellenbosch at (371) and UKZN at 417. 
UCT was placed third, followed by WITS, which was placed fifteenth; next was US in twenty-first position, then UKZN in forty-fifth position and finally UP in seventy-eighth position. The World QS rankings listed UP at 471-480 and UKZN at 501-550 (MacFarlane, 2013; Quacquarelli Symonds Limited, 2014). According to Gerda Kruger, executive director of Communication and Marketing at UCT, "a good performance in international rankings does assist in sending out the message that world-class education is available in South Africa. Both prospective students and academics around the world use the rankings to decide where they want to study and advance their academic careers" (cited in MacFarlane, 2013). WITS vice chancellor, Adam Habib argues that "even if we had the right number of academics [SA], it is important to have an international professoriate because it brings a cosmopolitan feel to the institution" (Govender, 2014b). These results reflected the desire of the top five universities in South Africa's policies to internationalize their programme offerings in order to attract more students and academics, both internationally and locally. For example, UCT has in its mission statement, "UCT aspires to become a premier academic meeting point between South Africa, the rest of Africa and the world. UCT will promote diversity and transformation within our institution and beyond, including growing the next generation of academics" (UCT, 2014). Another example of an institution striving to become a destination of choice for international academics is the mission of UKZN to become the "Premier University of African scholarship" and a "center for academic excellence" (UKZN, 2014).

\section{Conclusion}

Results of the study found that expatriate academics in SA fit the profile of highly skilled talent, in that they are younger than their local colleagues and are highly qualified, the majority of expatriate academics in SA higher education holding doctoral degrees. WITS was ranked in pole position and UCT was ranked second, over the three years examined in terms of recipient universities of expatriate academics. In 2014, UKZN was ranked third amongst all the public universities in terms of the number of expatriate academics employed. The reasons for this include the attractiveness of the host institution in terms of reputation (research and teaching) and location. Both these universities are ranked amongst the Top 500 in the world according to international rankings scales. Zimbabwe has been the largest single country supplier of expatriate academics to SA institutions of higher learning over the three years. Other major suppliers were Europe, Asia and the Americas. However, expatriates were found to be slightly younger than their local colleagues. Both the majority of SA academics and expatriate academics are males. Expatriate academics hold more doctoral degrees than their local colleagues over the three years examined. SA academics hold more Masters, Honours and post-graduate degrees than their expatriate colleagues.

Limitations and directions for future research: This study is exploratory and involves a single professional group in South Africa and hence only apply to academia in South Africa, therefore these findings would not be generalizable to other fields. Due to the fact that this study used secondary data collected from both HEMIS no further insight could be gathered regarding the context within which the recruitment of these academics could have taken place, thus the methodology employed in this study is in itself a limitation. Finally, the data available from both HEMIS are captured in the year after the academic year is over, therefore a time lag results in data available for analysis being already a year old. The study has attempted to create knowledge not previously researched in the South African context. Therefore these findings will be useful to other researchers in order to indicate the areas of focus such as patterns of inflows of the highly skilled, motivations of those that immigrate to South Africa and their experiences here in South Africa. Further research is required in terms of the challenges and opportunities these expatriates face in South Africa and how best organizations can manage this experiences to truly harness the true potential of these highly skilled individuals.

\section{References}

Altbach, P. G. (1996). The international academic profession: Portraits of fourteen countries. Princeton, MA: Carnegie Foundation for the Advancement of Teaching.

Altbach, P. G. (2004). Globalisation and the University: Myths and realities in an unequal world in the National Education Association (ed.) The NEA 2005 Almanac of Higher Education. Washington DC, pp. 63-74.

Altbach, P. G. \& Knight, J. (2007) The Internationalization of Higher Education: Motivations and Realities. Journal of Studies in International Education, 11(3-4), 291-305. 
Altbach, P. G., Reisburg, L. \& Pacheo, I. F. (2012). Academic Remuneration and Contracts: Global trends and realities in Altbach, P.G., Reisburg, L., Yudkerich, M., Androushchak, G. and Pacheo, I.F. (eds.) Paying the Professoriate: A Global Comparison of compensation and contracts. UK: Routledge, pp. 3-20.

Altman, Y. \& Baruch, Y. (2012). Global Self-Initiated Corporate Expatriate Careers: A new era in International Assignments? Personal Review, 41(1), 233-255.

Aycan, Z. \& Eskin, M. (2005) Relative contributions of Child care, spousal support and organizational support in reducing work-family conflict for men and women: The Case of Turkey. Sex Roles, 53(1), 453-471.

Baruch, Y. \& Hall, D. T. (2004). The academic career: A model for future careers in other sectors? Journal of Vocational Behaviour, 64, 241-262

Best Global Universities (2014) Global Universities Search: South Africa [Online]. Available at: http://www.usnews.com (Accessed: 30 October 2014).

Bhorat, H., Meyer, J. B. \& Mlatsheni, C. (2002). Skilled labour migration from developing countries: Study on South and Southern Africa. International Migration Papers 52. [Online] International Labour Office, Geneva. Available at: http://www.ilo.org/public/english /protection/migrant/ download/imp /imp52e.pdf. (Accessed: 22 Aug 2011).

Bissekar, C. \& Paton, C. (2005). No sacred cows.Financial Mail, 29 July, pp.18-20.

Centre for Development and Enterprise. (2007a). Skills, growth, and migration policy: Overcoming the 'fatal constraint'. Pretoria: CDE.

Cloete, N., Bailey, T., Pillay, P., Bunting, I. \& Maassen, P. (2011). Universities and economic development in Africa. Cape Town: Centre for Higher Education and Development.

Dickmann, M. \& Baruch, Y. (2011). Global Careers, NY New York: Routledge.

Govender, P. (2014a). Millions to be spent on Drive to transform Varsities. Sunday Times, 14 September 2014 [online] Available at http://www.thetimesnewspaperdirect.com. (Accessed 29 September 2014).

Govender, P. (2014b). Varsities casting recruiting nets wide. Sunday Times, 5 October 2014 [Online] Available at http://www.thetimesnewspaperdirect.com (Accessed 6 October 2014).

IEASA. (2011). In leaps and bounds: Growing higher education in South Africa, Higher Education in Context report. Available at http://www.ieasa.org . (Accessed: 23 February 2013).

Inkson, K. \& Myers, B. (2003). The Big OE: International travel and career development. Career Development International, 8(4), 170-181.

Jansen, L. (2013). SA academics amongst the highest paid. Mercury, 30 September [Online]. Available at: http://www.iolnews.co.za. (Accessed: 14 August 2014).

Kisshun, R. (2007). The Internationalization of Higher Education in South Africa: Progress and Challenges. Journal of Studies in International Education, 11(1), 455-469.

Kotecha, P., Lotz-Sisitka, H. \& Urquhart, P. (2014). SARUA Climate Change Counts Mapping Study: South Africa. Volume 2. Report 8. Johannesburg: SARUA.

Kotecha, P., Wilson-Strydom, M. \& Fongwas, S. N. (2012a). A Profile of higher education in Southern Africa. Volume 1: A Regional Perspective. Johannesburg: SARUA.

Knight, J. (2006). Cross border education: An analytical framework for program and provider mobility, in Smart, J.C. (ed.) Higher education: Handbook of theory and research. Dordrecht: Springer, pp. 345395.

Lewis, J. (2011). Brain drain. Crisis Magazine, Fall 2011, pp.27-29.

MacFarlane, D. (2013). Five SA universities ranked in Top 100 emerging economies list. Mail and Guardian, 4 December [Online]. Available at: http://www.mg.co.za. (Accessed 14 August 2014).

Maharaj, A. (2011). The impact of globalization on the South African higher education institutions: Patterns of academic inflow into the South African higher education system. International Journal of Arts and Sciences, 4(5), 80-98.

MORE2. (2013). Support for the continued data collection and analysis concerning the mobility patterns and career paths of researchers. European Commission. Brussels. August 2013.

Nerdrum, L. \& Sarpebakken, B. (2006). Mobility of Foreign Researchers in Norway. Science and Public Policy, 33(3), 217-229.

Ngcobo, G. (2013). Prof Takes on UKZN. Witness, 10 October 2013 [Online]. Available at: http//:www.witness.co.za. (Accessed: 11 October 2013).

Quacquarelli Symonds. (2014). Quacquarelli Symonds World University Rankings 2013/2014 [Online]. Available at: http://www.topuniversities.com/qs-world-university-rankings. (Accessed: 18 August 2014). 
Rasool, F. (2010). The role of skills immigration in addressing skills shortages in South Africa. Unpublished Doctoral Thesis. North West University, Potchefstroom.

Rasool, F., Botha, C. \& Bisschoff, C. (2012). The effectiveness of South Africa's immigration policy for addressing skills shortages. Managing Global Transitions, 10(4), 399-418.

Regenesys Business School. (2013). Education forum challenges of higher education in South Africa. Available at: http://www.regenesys.ac.za (Accessed: 13 October 2013).

Richardson, J. \& Zikic, J. (2007). The darker side of an international academic career. Career Development International, 12(2), 164-186.

Rodriguez, J. K. \& Scurry, T. (2014) Career capital development of self-initiated expatriates in Qatar: Cosmopolitan globetrotters, experts and outsiders. International Journal of Human Resource Management, 25(2), 190-211.

SARUA. (2011). Building higher education capacity through academic mobility. Johannesburg: SARUA.

Saunders, M., Lewis, P. \& Thornhill, A. (2003). Research methods for business students. $3^{\text {rd }}$ edition. Harlow: Prentice Hall.

Sehoole, C. T. (2012). The Unequal Playing field: Academic remuneration in South Africa' in Altbach, P.G.; Reisburg, L.; Yudkerich, M.; Androushchak, G. and Pacheo, I.F (eds.) Paying the Professoriate: A Global comparison of compensation and contracts. Routledge: UK.

Selmer, J. \& Lauring, J. (2013). Cognitive and affective reasons to expatriate and work adjustment of expatriate academics. International Journal of Cross Cultural Management, 13(2), 175-191.

Sowetan (2012). South Africa to open two new universities, 24 April 2012 [Online]. Available at: http://www.sowetanlive.co.za/news/2012/24/. (Accessed: 24 May 2012).

Suutari, V. \& Brewster, C. (2000). Making their own way: International experience through self-initiated foreign assignments. Journal of World Business, 35(4), 417-436.

The Presidency. (2006a). Accelerated and shared growth initiative for South Africa (AsgiSa). Pretoria: The Presidency.

The Presidency. (2006b). Joint initiative on priority skills acquisition (Jipsa). Pretoria: The Presidency.

Trembly, K. (2004). Links between academic mobility and immigration'. A conference paper delivered at the Symposium on International Labour and Academic Mobility: Emerging trends and Implications for Public Policy. Toronto: 22 October 2004.

University of Cape Town. (2014). Available at http://www.uct.ac.za(Accessed: 14 September 2014)

University of KwaZulu-Natal. (2014). Available at http://www.ukzn.ac.za . (Accessed 14 September 2014).

Welch, I. (2003). The Higher Education Debate-Reignited. Nursing Times, 99(36), 17-25. 